\title{
Relation of sour cherry blooming dynamics and meteorological variables
}

\author{
Lakatos, L. ${ }^{1}$, Szabó, T. ${ }^{2}$, Szabó, Z. ${ }^{3}$, Soltész, M. ${ }^{3}$ \& Nyéki, J. ${ }^{3}$ \\ ${ }^{1}$ University of Debrecen, Centre for Agricultural Sciences and Engenering, Hungary \\ ${ }^{2}$ Fruit Research and Extension Institute of Ujfehértó, Hungary \\ ${ }^{3}$ University of Debrecen, Institute for Research and Development, Hungary
}

\begin{abstract}
Summary: The aim of our research was to identify the role of weather parameters in the development of the start date and length of blooming. In order to achieve this, we examined how meteorological conditions of a particular year influence the start date and length of blooming in different years (dry, wet, cool, hot, sunny, cloudy). The meteorological parameters were the following: maximum temperature, minimum temperature, average temperature, precipitation, length of sunlight, difference of daytime and nightime temperatures, potential evaporationPET, Huglin-index, Winkler-index, climatic water balance which can be calculated as a difference of precipitation and potential evaporation. In this study we wanted to find out whether early start of blooming results in a longer blooming period or if there is a generally faster blooming period when blooming starts later. Based on the results we can say that early start of blooming resulted in extended blooming period for three sour cherry varieties at the examined production sites. The start of blooming showed the closest relation with the difference of average daytime and nightime temperatures of the 30-day period prior to blooming. Significant relation was also detected with the thermic indexes as well as with maximum temperatures, climatic water balance and the degree of potential evaporation. We examined how weather 30 days prior and during blooming influenced the length of phases. Results showed that precipitation prior and during blooming is in significant relation with the length of blooming. We detected significant relation between daytime and nightime temperature differences and the length of blooming. The nature of the relation indicates that blooming periods were shorter in case of increasing temperature differences. We found that shorter blooming lengths occurred when maximum temperatures averaged between $13.5-14.5^{\circ} \mathrm{C} 30$ days prior to blooming when examining the relation between blooming length and maximum temperature. If the average of maximum temperatures was below $13{ }^{\circ} \mathrm{C}$ or exceeded $15{ }^{\circ} \mathrm{C}$ during this period, then we could calculate with a blooming period longer than ten days. We proved that little precipitation and high temperature accelerates physiological processes, therefore we could calculate with an accelerated blooming and shorter blooming period.
\end{abstract}

Key words: beginning of blooming, length of blooming, difference of night and day temperature weather conditions (dry, wet, cold, warm, sunny, cloudy) thermal indexes (Winkler, Huglin)

\section{Introduction}

The blooming phase of sour cherry Lakatos et al. (2008) has previously been dealt with. Significant relation can be detected between the differences of daytime and nightime temperature and length of blooming. The nature of the relation indicates that blooming phase was shorter in case of increasing temperature difference. On spring days when the difference between daytime and nightime temperatures is high, generally high daytime temperatures occur. These significantly accelerate blooming phases. In case of cloudy and wet weather, the difference between daytime and nightime temperatures is generally low, which lengthens the blooming phase. The length of blooming showed the closest relation with the daily average temperature.

Not only average temperature, but minimum temperature and maximum temperature also showed significant relation the length of the blooming phase. Blooming phases were significantly shorter when temperatures were higher. In this examination, were are taking new parameters into consideration, such as potential evaporation, the Huglin- index (Huglin 1978, 1986), and the Winkler-index (Winkler et al., 1974). These indexes were were tested with grape cultures (Szenteleki et al., 2007a, Ladányi et al., 2007). The abovementioned authors got good results with these cultures regarding the applicability of the indexes. Our results have also supported that the temperature and moisture indicators developed for grape can be applied for other fruits as well. The dependence of blooming on weather was examined with classification into different blooming-time categories.

Eight blooming-time categories were identified when examining Maliga (1953) cherry and sour cherry varieties at the same time. We can also mention the works of Kellerhals (1986) and Ritiu $(1975,1976)$ in connection with sour cherry blooming.

Békefi et al. (2000) examined the blooming time of many sour cherry varieties. Previous data for 'Pándy sour cherry' were primarily connected to fertilisation Pejkic (1966). His results showed that the rate of yield formation was highest in the first day following pollination and decreased significantly as time progressed. Fruit did not form 72 hours following pollination. If pollination and 
fertilisation does not happen 48 hours within the time flower bursting, the embryo sac and ovule degenerates and yield formation does not occur. Satisfactory fertilisation requires pollination when flowers burst or the following day at the latest. The lowest difference of yield formation among flowers bursting in different times was detected with midterm blooming varieties. The lowest yield formation was detected with flowers blooming latest when examining latest blooming varieties. Pollination had to occur 40 hours within the burst of flowers for good yield formation in sour cherry varieties.

According to Nyéki (1989) the rate of simultaneous blooming has to be over $70 \%$ with self-sterile varieties to ensure safe pollination. The rate of simultaneous blooming has to be at least over $80 \%$ for 'Pándy sour cherry' varieties. Over $70 \%$ simultaneous blooming can be ensured by varieties belonging to the same blooming-time categories, if the varieties are classified into 3 bloomingtime categories (early, medium, late). Simultaneous blooming of two varieties is not sufficient, if their rate is below $50 \%$ they cannot be planted together. Sufficient pollen supply and simultaneous blooming ensuring safe pollination can only be achieved by planting many (2-4) pollen varieties jointly.

\section{Materials and methods}

\section{Production site conditions}

Újfehértó belongs to geographical landscape unit of Nyírség, where the typical relief and soil conditions can be found. The dominant soil types are humus and sand formed on sandy rocks, Eastern European brown forest soils and meadow soils. The surface of the area at the Research Station is slightly undulate with macro and micro pits. The soil type is non-carbonic sand with humus formed on silt sand. The thickness of the humus layer is $60 \mathrm{~cm}$ according to the soil examination. The soil $\mathrm{pH}$ is slightly acidic, the organic matter content is medium within its category and the physical type is sand. Groundwater level is below $250 \mathrm{~cm}$.

\section{Material}

Examinations related to varieties were continuously were carried out at production plants, gardens and orchards from 1972. We gradually included all selected sour cherry varieties in Northeast Hungary. The observations were continuously carried out in all cases prior to national qualification and following the launch of production or from the first year. The examined varieties at Újfehértó Research Station were at identical production site and production conditions (growing area, crown shape, phyto and agrotechnique, plant protection). The samples for examination were and are still collected at random block arrangement experimental plantations, accepted and described by the National Agricultural Qualification Institute.

\section{Method}

Phenological observations related to the start of blooming were carried out by professionals over the past 26 years. This guarantees the reliabilty of data and accuracy of drawn conclusions. In case of blooming, not only the time of flower bursting but the mature flower formation and the end of blooming were also recorded. In this current study, we are only examining the dependency of blooming starts on weather factors. We believe that one decisive period that influences the formation of blooming is the period from October $1^{\text {st }}$ of the previous year to the start of blooming. The other decisive period is the one month period prior to the start of blooming. We are examining the meteorological effects of these two periods on the formation of the start of blooming.

We categorised years through statistical evaluation of the data sequences (average and standard deviation). We defined the periods prior to blooming as wet, warm and cloudy in case of values larger than the average and standard deviation sums. We classified the specfic year as average within the average $+/-$ deviation interval. It can be seen from table 1 ., which years can be regarded as dry, wet, cloudy, sunny, cool or warm.

The biggest problem with the categorisation of years based on the quantity of precipitation is that it does not provide information about the nature of deviations. If larger quantity of precipitation occurs at the end of a longer period and the quantity with this amount exceeds the average of many years, then even severe water deficiency could occur during the period due to uneven precipitation supply. Therefore, the qualification (dry, wet) of a longer period based on quantities is only possible if the exact distribution is also known. That is to say that daily precipitation data also has to be considered when assessing a period. In case of other parameters, the distribution typical for a specific period is also important, but such extreme distribution is not typical for neither temperature nor length of sunlight than for precipitation. Table 1 was prepared by taking these considerations into account.

Statistical evaluation was carried out by using SPSS 13.0 for Windows application. We determined regressions, frequencies and deviations. The functions were illustrated by using Excel application.

\section{Results}

The start of blooming highly depends on weather for most fruit-producing plants. High temperature significantly accelerates the start of blooming and naturally the development of its length. At the same time, cool, spring weather considerably delays the start date of blooming. Based on the provided 26-year data sequence, we can say that the period between the earliest and latest blooming starts can reach up to 26 days.

We found significant relation between the start of blooming and length of blooming in case of all three 
Table 1. Weather characteristics and start date of blooming at the three sour cherry cultivars

\begin{tabular}{|c|c|c|c|c|c|c|}
\hline & \multicolumn{3}{|c|}{ Wether characteristics } & \multicolumn{3}{|c|}{ Start date of blooming from 1st of January } \\
\hline & precipitation & Sunshine duration & temperature & Újfehértói fürtös & Kántorjánosi & Debreceni bőtermő \\
\hline 1983 & average & average & average & 111 & 111 & 110 \\
\hline 1984 & dry & average & hot & 116 & 116 & 114 \\
\hline 1985 & average & average & cool & 114 & 113 & 113 \\
\hline 1986 & wet & average & average & 113 & 112 & 112 \\
\hline 1987 & average & sunny & average & 121 & 121 & 121 \\
\hline 1988 & wet & average & cool & 120 & 119 & 119 \\
\hline 1989 & average & average & average & 102 & 101 & 101 \\
\hline 1990 & dry & sunny & average & 95 & 94 & 94 \\
\hline 1991 & average & cloudy & hot & 107 & 106 & 106 \\
\hline 1992 & average & average & average & 113 & 113 & 113 \\
\hline 1993 & average & average & average & 117 & 118 & 117 \\
\hline 1994 & wet & cloudy & average & 107 & 107 & 108 \\
\hline 1995 & average & average & cool & 114 & 113 & 113 \\
\hline 1996 & average & average & average & 117 & 116 & 116 \\
\hline 1997 & dry & average & average & 120 & 120 & 120 \\
\hline 1998 & average & cloudy & hot & 112 & 112 & 112 \\
\hline 1999 & average & average & average & 105 & 104 & 104 \\
\hline 2000 & average & cloudy & average & 108 & 107 & 108 \\
\hline 2001 & average & average & average & 110 & 108 & 111 \\
\hline 2002 & dry & average & average & 102 & 101 & 101 \\
\hline 2003 & average & average & cool & 117 & 116 & 116 \\
\hline 2004 & wet & average & average & 110 & 109 & 109 \\
\hline 2005 & average & sunny & average & 109 & 108 & 108 \\
\hline 2006 & wet & average & average & 114 & 113 & 112 \\
\hline 2007 & dry & sunny & hot & 102 & 102 & 101 \\
\hline 2008 & average & average & average & 105 & 104 & 104 \\
\hline
\end{tabular}

examined sour cherry varieties. The strongest relation was detected with the 'Kántorjánosi' variety.

Based on the results we can say that as long as blooming occurs in the beginning of April, then it generally lasts 14-15 days. If it occurs late April, then it usually only lasts $7-10$ days on average.

When observing the distribution of blooming start frequency, we can establish that blooming of sour cherry began 90-125 days between the period 1983-2008. 'Újfehértói fürtös' a bit later, then followed by 'Kántorjánosi', and 'Debreceni bőtermő'. For these two, it is typical that the blooming occurs about the same time and with the same dynamics (Figure 1).

Length of blooming was between 6 and 19 days with all three examined sour cherry types. Based on the length of

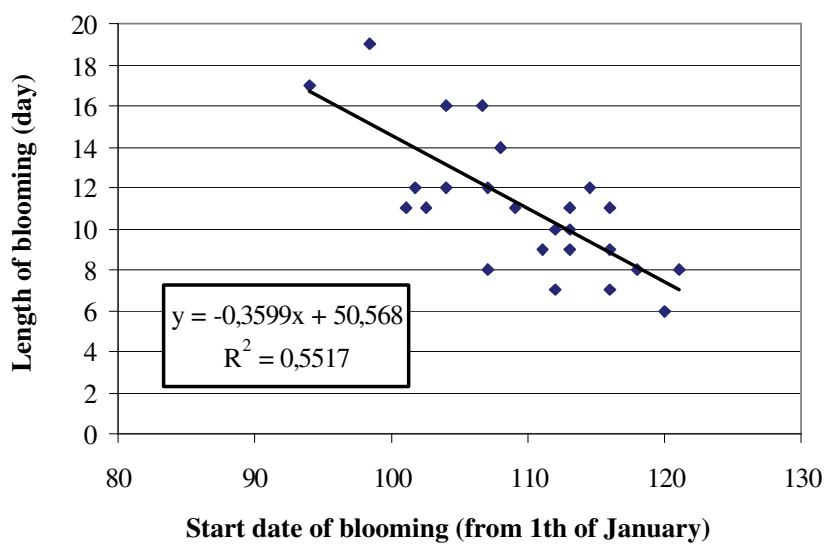

Figure 1. Relationship between the start date and length of blooming at 'Kántorjánosi' cultivar (Újfehértó 1983-2008) 
blooming we can establish that the longest blooming period is typical of 'Újfehértói fürtös', while the shortest is a typical feature of 'Debreceni bőtermő' (Figure 2). Significant difference cannot be detected among the varieties.

We believe that it is not only weather during blooming that plays an important role in the formation of blooming length, but also the meteorological conditions one month prior to blooming. We have produced the meteorological parameters of the 30-day period prior the start of blooming to

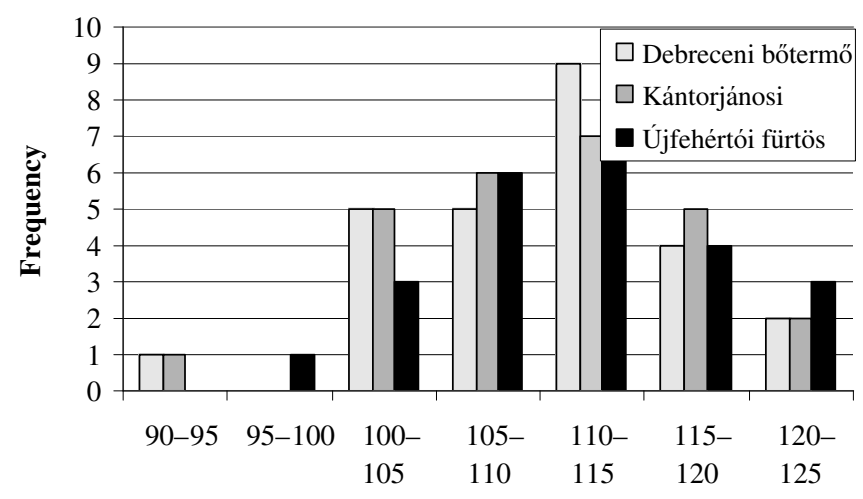

Start date of blooming from January 1 st

Figure 2. Distribution of start date of blooming at the examined cultivars (Újfehértó 1983-2008)

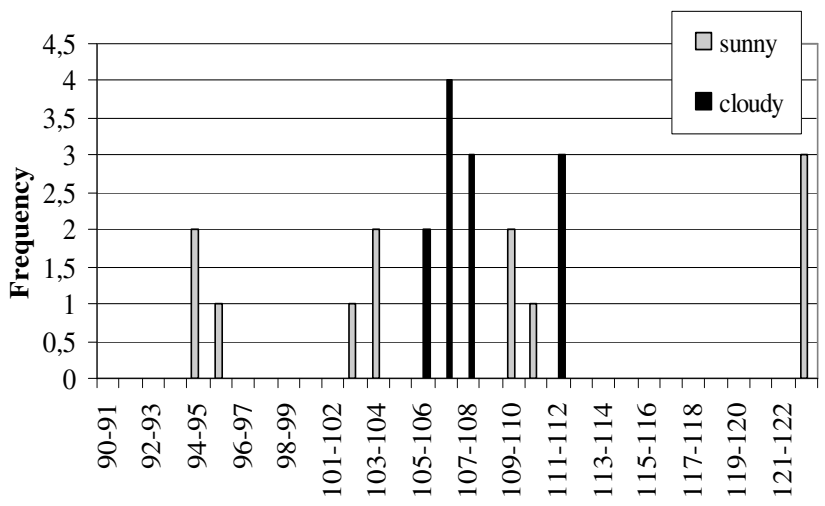

Start date intervals of blooming (from 1st January)

Figure 3. Distribution of the start date of sour cherry blooming at sunny and cloudy years

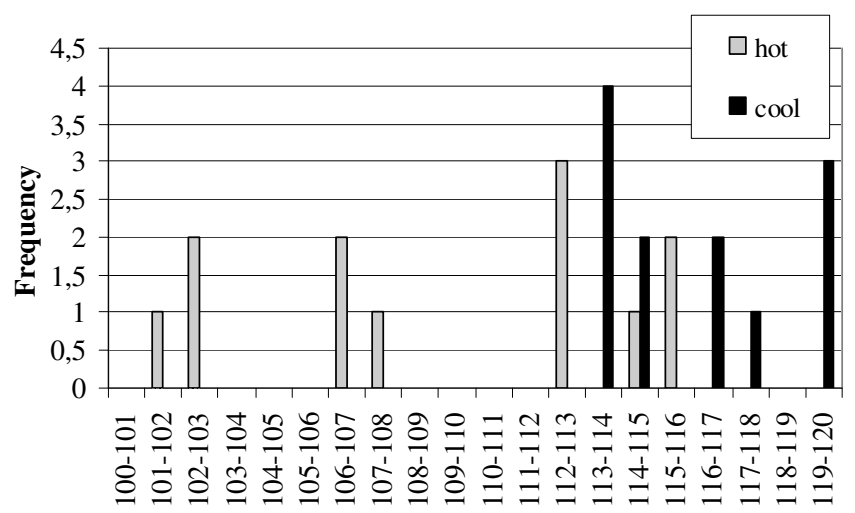

Start date intervals of blooming (from 1st January)

Figure 4. Distribution of the start date of sour cherry blooming at hot and cool years prove this assumption. The examined variables were the following: difference of daytime and nightime temperatures, precipitation, maximum-, minimum-, as well as average temperature, climatic water balance, Huglin-index, Winklerindex. The examinations were carried out according to different years. We examined the distribution of blooming length in cases when the weather 30 days prior to blooming was mostly cloudy or sunny. We also carried out the previously mentioned distribution examinations for wet and dry years. Cool and warm years were classified into the third year category. Year categorisation was carried out on a mathematical basis. In the first step, we formed the average of many years, then the deviation of the sample for the given period. We assumed that if the value for the period is higher or lower than the average $+/-$ half of the deviation, then the specific year was categorised as wet or dry. Based on similar method we could also distinguish between cloudy-sunny, and cool and warm years. If we examine how blooming lengths formed when the 30 days prior blooming were sunny and cloudy, we can come to the following findings. Blooming periods are generally shorter in case of sunny years than in cloudy ones. Close to three-week blooming lengths are frequent in cloudy years, while we can come across 16-18 day long blooming period lengths at most in sunny years.

If we examine the values of the lengths of sunlight prior to blooming, we can see that blooming begins significantly earlier but they are longer in case of sunny weather. Sunny weather is generally accompanied by milder weather, however it is not rare that spring is interrupted by colder spells. The frequency distribution of blooming start shows that in case of cloudy, overcast weather the distribution of the beginning of blooming shows lower deviation. This means, that temperature interval of overcast weather is much shorter than that of sunny periods in the spring period. In case of sunny years we can experience longer blooming lengths than in the case of cloudy years. We believe that this is due to the fact that sunny years can be warm and cool in this period of the year.

The warm weather condition of the spring period significantly accelrates the start of blooming. We can expect blooming to start up to two weeks earlier than in coller years (Figure 3). Late blooming start shows less wide spectrum of deviation in cool years, that is to say that deterministic effects are strong in case of late beginning of blooming. At the same time, earlier start of blooming is characterised by significantly higher weather sensitivity. In this case, it is far more likely that temperatures will fall during blooming which can slow down the blooming process.

When examing the blooming length distribution of cool and warm years, we can see that though long blooming is more frequent in cool years, it is not rare in warmer years either (Figure 4). The fact that the average temperature of a period is high does necessarily mean that it is true for every day of the period. Such years occur, when following a period with exceptionally high temperatures the temperature falls significantly, which slows the blooming process down, average temperature at the same time is still above average, so we can talk about a warm period. We cannot disregard that 
as long as a warm period proves to be wetter than average, it also slows down the blooming process, so we can take longer blooming phases into account in both warm and wet years. The length of blooming in warm years is 5-12 days, while in cool years it is between 9-19 days (Figure 4).

We examined the effect of climatic water balance on the formation of the beginning of blooming from the higric parameters. We found significant relation between climatic water balance and the beginning of blooming in the phase lasting from October 1. of the previous year to the start of blooming. The relation shows that both high water deficiency and water surplus slow down the start of blooming. The earliest start of blooming was experienced with approximately $+50 \mathrm{~mm}$ water balance. High water surplus is accompanied by cooler than average weather and consequently the start of blooming occurs later. Significant water surplus slows the rate of physiological processes and a delayed start of blooming can be expected as a result.

We can notice that blooming is more accelerated and shorter in dry years than in wet years. The length of blooming is typically 6-16 days in dry years, while 6-19 days are typical in wet years. Water deficient condition accelerates the blooming process, while with good water supply the length of blooming is commonly between 18-19 days.

The results of examination indicated that the length of blooming is 4-5 days longer than in wet years than in dry ones. Water deficient condition significantly accelerates the generative processes of plants and this is apparent in the formation of blooming dynamics. This is a detectable form of adaptation to unfavourable weather conditions, when plants turn most of their energies to survival and yield formation, moderating their vegetative development.

We also examined how evaporation sums of the previous year influence the blooming time of the following year. Results showed that blooming occurred later with low and high evaporation sums. If the evaporation value of the examined period was close to $210-220 \mathrm{~mm}$, we could calculate with an early blooming start. In case of little evaporation, we can assume that weather is cool. This significantly slows the occurrence of blooming. We can say that neither very warm nor very cool weather is favourable for early blooming. We can establish that the start of blooming is delayed by 10-12 days above $270 \mathrm{~mm}$ and below $150 \mathrm{~mm}$ of evaporation.

Average difference of daytime and nightime temperatures thirty days prior to blooming start shows significant relation with the start date of blooming. The higher the difference between daytime and nightime temperatures, the later blooming could occur. In case of high difference this can be explained by quite high maximum daytime temperatures, which can significantly accelerate the process of bud opening. If the average difference of daytime and nightime temperatures reaches $5-6{ }^{\circ} \mathrm{C}$, we can calculate with a blooming start of 95-105 days, while the start of blooming is between $110-120$ days with $3-4{ }^{\circ} \mathrm{C}$ of difference. Therefore we can state that as long as the average daytime and nightime temperature difference increases by $1{ }^{\circ} \mathrm{C}$, it accelerates the start of blooming by about ten days (Figure 5).
The maximum temperatures of the preceding 30-day period also show significant relation with the start of blooming. We can establish that blooming starts much earlier with high maximum temperatures than in case of lower values. If the average of daily maximum temperatures increases by 1 ${ }^{\circ} \mathrm{C}$, it accelerates the start of blooming by six days.

We found significant relation with both the Huglin and Winkler index from the compound thermic indexes. Results show that with $700-800{ }^{\circ} \mathrm{C}$ heat sums, we could calculate with a blooming start 10-15 days earlier than with heat sums between $400-500{ }^{\circ} \mathrm{C}$. Blooming starts occur later in case of very high heat sums. An explanation for this is that in case of strong warming up, especially if it happens at an early period according to the calendar, it does not have a significant blooming accelerative effect. The value of the index will be high, but early blooming does not occur. The Huglin-index is therefore suitable for estimating the formation of blooming start, however it requires further adjustments and consideration of the length of the previous period.

In case of the Winkler-index we found that as long as its typical value is between 30 and $40{ }^{\circ} \mathrm{C} 30$ days prior to the start of blooming, then we can expect the earliest start of blooming. Between $50-60^{\circ} \mathrm{C}$, and $10-20{ }^{\circ} \mathrm{C}$ of Winkler-index values, blooming starts occur two weeks later (Figure 6).

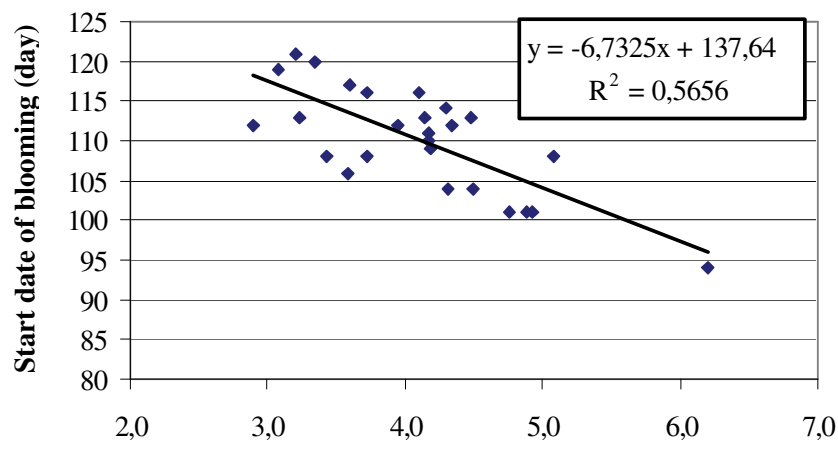

Difference of daytime and nightime temperatures $\left({ }^{\circ} \mathrm{C}\right)$

Figure 5. Relationship between the average difference of daytime and nightime temperatures thirty days prior to blooming start and the start date of blooming at "Debreceni bőtermő" cultivar (Újfehértó 1983-2008)

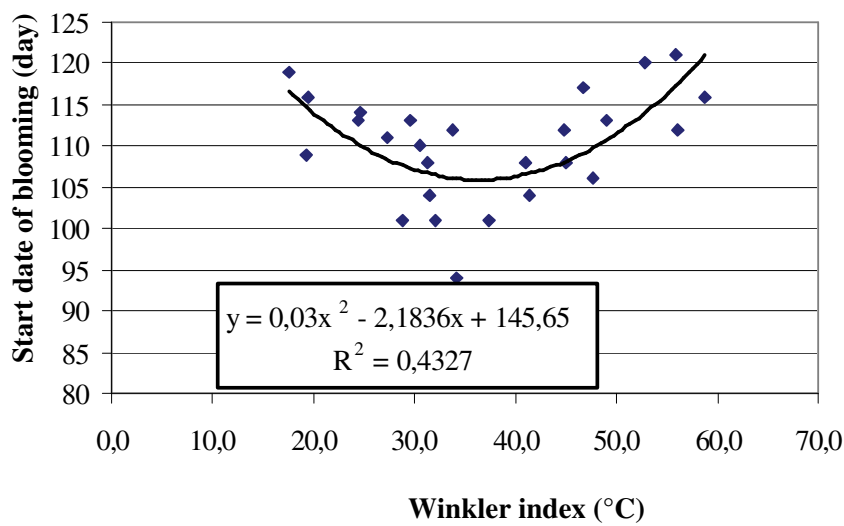

Figure 6. Relationship between the average value of Winkler index thirty days prior to blooming start and the start date of blooming at "Debreceni bőtermő" cultivar (Újfehértó 1983-2008) 
Temperatures prior blooming also show significant relation with the length of blooming. We found that shorter blooming lengths occurred when the average of maximum temperatures was between $13.5-14.5^{\circ} \mathrm{C} 30$ days prior to blooming. As long as the average of maximum temperatures typical for the period remained below $13{ }^{\circ} \mathrm{C}$ or exceeded $15^{\circ} \mathrm{C}$, we could calculate with blooming exceeding ten days.

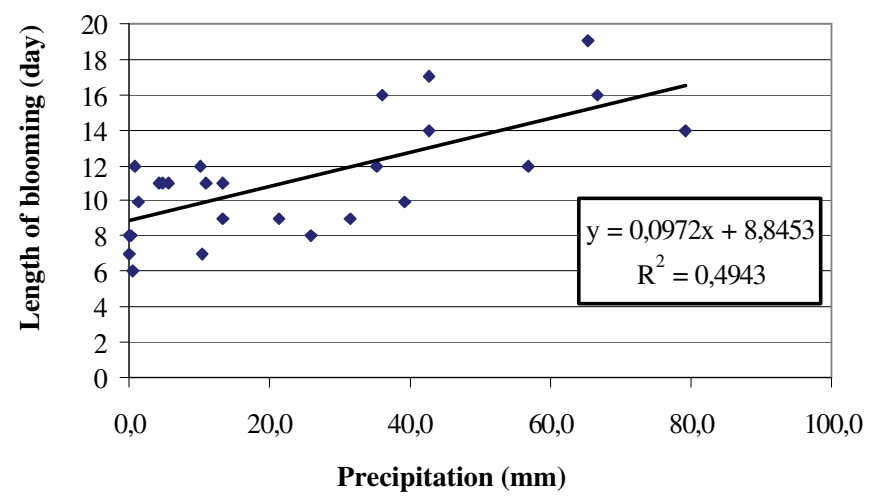

Figure 7. Relationship between the lenght of blooming and amount of precipitation during the bloming at "Kántorjánosi" cultivar (Újfehértó 1983-2008)

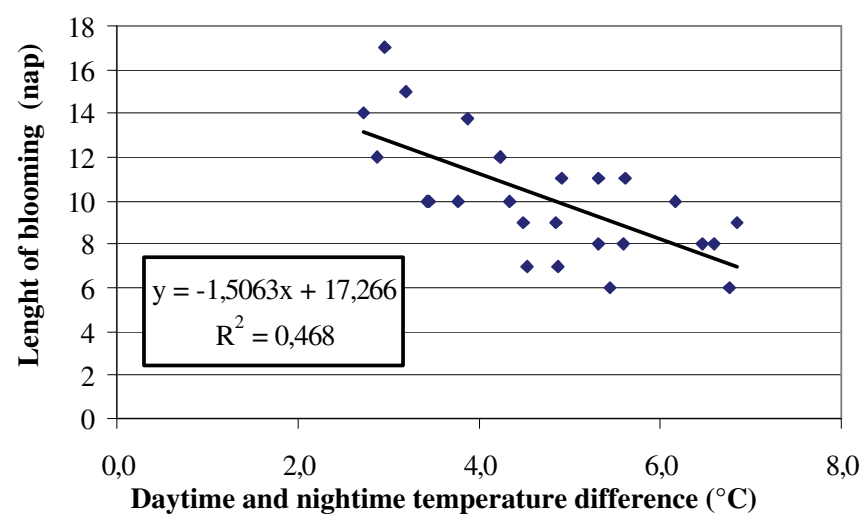

Figure 8. Relationship between the lenght of blooming and average value of daytime and nightime temperature difference during the bloming at "Újfehértói fürtös" cultivar (Újfehértó 1983-2008)

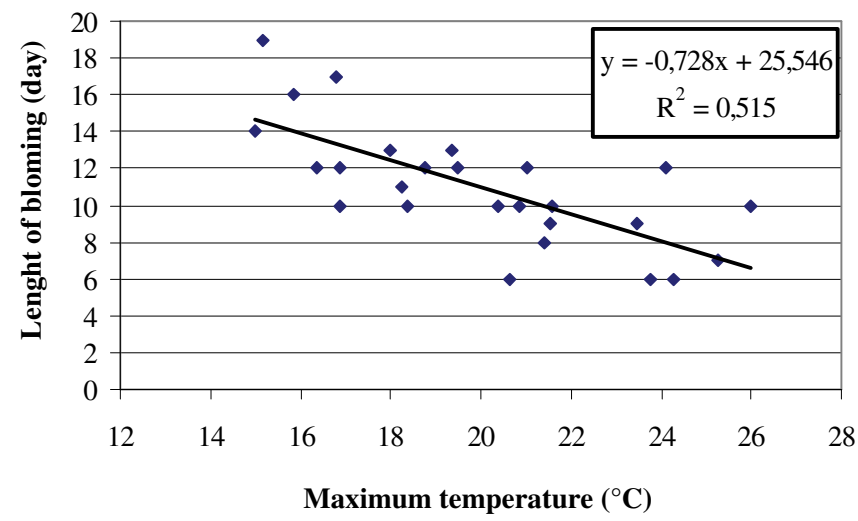

Figure 9. Relationship between the lenght of blooming and average value of maximum temperature during the bloming at "Debreceni bötermö" cultivar (Újfehértó 1983-2008)
The value of Huglin-index for the month prior to blooming also shows that with $180-200{ }^{\circ} \mathrm{C}$ index values, the length of blooming is around 8 days, while in case of index values above $270^{\circ} \mathrm{C}$ and below $120^{\circ} \mathrm{C}$, we can calculate with a blooming period of over 12 days .

Weather during blooming has an undoubtedly important effect on the length of the phase. We will introduce some significant function relations, which were identified with regression examinations over and during the phase length among the meteorological parameters.

Examinations showed that the length of the phase increase proportionally with the increase of precipitation during the blooming. In case of $20 \mathrm{~mm}$ precipitation, the length of phases were generally between 10-12 days, in case of precipitation amounts exceeding $60 \mathrm{~mm}$, we could experience phase lengths of over 15 days (Figure 7).

We found significant relation between the difference of daytime and nightime temperatures typical for the phase and the length of blooming. Results show as long as the difference is high, exceeding $6{ }^{\circ} \mathrm{C}$-ot difference between daytime and nightime temperature, then we can expect a blooming length of one week, while with temperature differences less than 4 ${ }^{\circ} \mathrm{C}$, we could experience blooming lengths of two weeks (Figure 8). If the daytime and nightime temperature difference is high, this results an intensive daytime warming and little loss of nightime respiration, which improves the rate of development, allowing a more efficient growth.

Maximum temperature showed the closest relation with the length of the phase from the temperature parameters. It is clear from Figure 12. that we can expect shorter blooming lengths with increasing maximum temperatures. The length of phase exceeds two weeks with maximum temperatures of $15-16^{\circ} \mathrm{C}$ during blooming, while with maximum temperatures above $24^{\circ} \mathrm{C}$, we can expect blooming lengths of one week (Figure 9).

Winkler-index values during blooming show that we can expect decreasing length of blossoming with increasing index values. We can state that in case of index value changes between 10 and 60, the decrease of blooming length is quite significant however, in case of values between 60 and 120 it is not considerable. In case of Huglin-index for blooming length, we can see that the length of blooming considerably decreases as an effect of increasing Huglin-index values between 20 and 200. 14-15 days are typical in case of index values of 20, while only around 8-10 days blooming lengths can be observed with Huglin-index values of around 200. The rate of blooming length decrease is moderate with index values over 200 .

\section{Conclusions}

Based on the introduced results we can establish that the start of blooming is primarily influenced by thermic factors. The effect of precipitation and the length of sunlight has insignificant effect on the start of blooming based on our database. We found strong relation among potential evaporation, the size of climatic water balance and the start 
of blooming. Plants of course need sufficient water supply for their optimal development. This is provided through sufficient soil moisture in the spring period. Since the rate of evaporation cannot be regarded as significant in in this early spring phase, a negative water balance does not necessarily mean that the requiered water supply is not present in soil. The amount of precipitation is especially valuable in the summer during the ripening period, as by this time there is not sufficent amount of water supply in the soil. The formation of precipitation amount prior to the ripening period has significantly larger impact on the development of ripening. Groundwater close to water capacity is of primary importance in the formation of blooming start, so the quantity of precipitation is less important among the factors.

We consider it a great advancement that the thermic indexes - the Winkler and Huglin index - developed for grapes, were tested for the examination of phenological times of orchards. Preliminary research confirmed that these indicators are suitable for characterising the development cycles of fruit bearing plants. Further testing and modification is necessary for better results.

We believe that more extensive testing of temperature and precipitation can significantly improve the quantification of production sites. We think it is required to examine additional indexes beyond the three introduced in the study. It is possible that some indexes will not provide convincing results in their original formula, so we find it especially important to review these indexes and to modify them if needed for domestic climatic conditions. With the help of developed values and indexes we can forecast how the weather risk factors of specific production sites will change in the future.

\section{References}

Békefi, Zs., Apostol, J., Boronkai, G. (2000): Acta Hortic. 538:117-122.

Huglin P (1978): Nouveau mode d'evaluation des possibilités héliothermique d'un milieu viticole C.R. Acad. Agric.: 1117-1126.

Huglin, P (1986): Biologie et ecologie de la vigue. Payot Lausanne. Paris: 372 pp.

Kellerhals, M. (1986): Schweiz. Zeitschrift für Obst- und Weinbau, 122 (13): 363-371.

Lakatos, L., Szabó, T., Solész, M., Sun, Z., Wang, Y., Szabó Z., Nyéki J. (2008): Időjárási változók hatása a meggy virágzástartamának alakulására. „Klíma-21” Füzetek, (53): 60-67.

Ladányi, M., Szenteleki, M., Erdélyi, É. (2007): The risk of Hungarian vine production from climate change aspect. OIV conference, Budapest, 2007.

Maliga, P. (1953): MTA. Agrártud. Oszt. Közl. 3 (1-2):177-215.

Nyéki, J. (1989): Csonthéjas gyümölcsűek virágzása és termékenyülése. MTA Doktori Értekezés, Budapest.

Pejkic, B. (1966): Rev. Res. Work. Fac. Agric. Univ. Beograd, 14 (422): 1-8.

Ritiu, C. (1975-76): Lucrari Stiintifice. 18-19 (197): 109-112.

Szenteleki, K., Ladányi, M., Szabó, É., Horváth, L., Hufnágel, L.-Solymosi, N.-Révész, A. (2007b): Introducing the KKT climate research database magagement sofrware. EFITA Conference, Glasgow, 2007.

Winkler, A. J. Cook, J.S., Kliewer, W. M. and Lider, L. A. (1974): General Viticulture. 143-144. University of California Press, Berkeley. 